\title{
Characteristics of transborder wood flow to sawmills in eastern Canada
}

\author{
by Nate Anderson ${ }^{1}$, René Germain² and Eddie Bevilacqua ${ }^{3}$
}

\begin{abstract}
This paper characterizes the wood procurement operations of Canadian sawmills within 300 kilometres of the Northern Forest, which is a 12 million hectare area of mixed hardwood and coniferous forest that spans 4 states in the northeastern United States. Based on data collected from a mail survey administered in 2006, wood procurement is quantified in terms of the percentage of supply from transborder sources, the geographic range of procurement operations, the relative importance of alternative sawlog sources, and perceived changes in the availability and quality of the sawlog resource. Over $1 / 3$ of the 5.17 million $\mathrm{m}^{3}$ of procurement reported in the survey originated in the United States. On average, mills that have little or no procurement in Canada routinely range 240 kilometres or more to meet procurement requirements, predominantly from roadside sources in the United States. Mills that procure all of their wood within Canada range 114 kilometres on average, and procure $73 \%$ of their wood supply from provincial Crown lands. A majority of mills in the sample reported that the quality of logs and the volume per log within their woodshed declined between 1994 and 2005. Based on a logistic regression model of 4 predictor variables, distance to the U.S. border and access to logs from provincial Crown lands are significant predictors of the use of transborder log sources. In addition to providing valuable baseline data, results suggest that mills without access to provincial Crown lands may be disproportionately impacted by high fuel prices and parcelization of private forest land in the United States. Results are discussed in light of these and other industry trends.
\end{abstract}

Key words: sawmill industry, log imports, international trade, wood procurement

\section{RÉSUMÉ}

Cet article fait état des opérations d’approvisionnement en bois des scieries canadiennes situées à moins de 300 kilomètres de la forêt nordique, à partir d'un territoire de 12 millions d'hectares de boisés feuillus mélangés et de forêts de conifères qui recoupe 4 états du nord-est des États-Unis. À partir des données recueillies lors d'un sondage effectué par la poste en 2006, l'approvisionnement en bois est exprimé en termes de pourcentage d’approvisionnement de sources transfrontalières, de la distribution géographique des opérations d’approvisionnement, de limportance relative des sources alternatives de billots et des modifications perçues dans la disponibilité et la qualité des billes de sciage. Plus du tiers des 5,17 millions de $\mathrm{m}^{3}$ de bois identifiés par le sondage provient des États-Unis. En moyenne, les scieries qui ont peu ou pas d'approvisionnement en provenance du Canada parcourent 240 kilomètres ou plus pour s'approvisionner, en grande partie de stocks entreposés en bordure de chemin aux États-Unis. Les scieries qui s'approvisionnent entièrement au Canada, parcourent 114 kilomètres en moyenne et obtiennent $73 \%$ de l'approvisionnement en bois des terres publiques provinciales. La majorité des scieries participantes a indiqué que la qualité des billes ainsi que le volume par bille de leur réserve de bois a diminué entre 1994 et 2005. Selon un modèle de régression logistique de 4 variables de prédiction, la distance pour se rendre à la frontière états-unienne et l'accessibilité à des billes provenant des terres publiques provinciales constituent des éléments de prédiction significatifs de l'utilisation de sources de billes transfrontalières. En plus de constituer des données de base valables, les résultats laissent entendre que les scieries sans accès aux terres publiques provinciales pourraient subir des conséquences disproportionnées par les prix élevés des carburants et du morcellement des boisés privés aux États-Unis. Les résultats sont discutés à la lumière de ces points et autres tendances reconnues au sein de l'industrie.

Mots clés : industrie du sciage, importation de billes, commerce international, approvisionnement en bois

\footnotetext{
${ }^{1}$ Research Assistant, 414 Bray Hall, State University of New York, Syracuse, NY 13210. E-mail: nmanders@syr.edu

${ }^{2}$ Associate Professor, 316 Bray Hall, State University of New York, Syracuse, NY 13210.

${ }^{3}$ Associate Professor, 301 Bray Hall, State University of New York, Syracuse, NY 13210.
} 


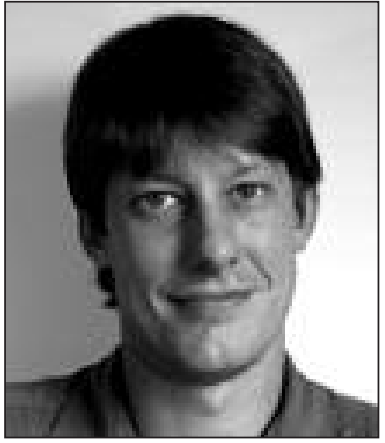

Nate Anderson

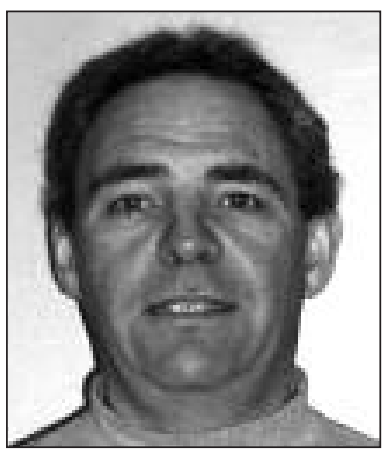

Eddie Bevilacqua

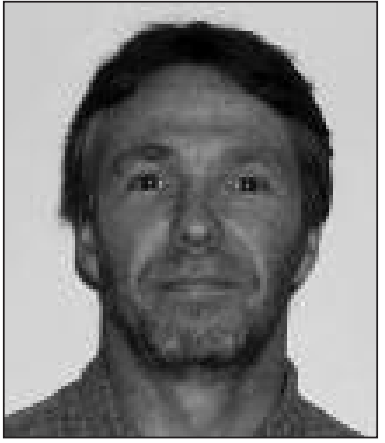

René Germain

\section{Introduction}

Log flow from the northeast U.S. to eastern Canada

Many sawmills in eastern Canada depend on private forests in the northeastern United States to meet part or all of their roundwood requirements. Transborder log sources are an especially important component of the wood supply for large mills close to the border. For example, in a study of sawmills in the ChauedièreAppalaches region of Southern Québec, Straussfogel et al. (2003) reported that $69 \%$ of the log supply for large mills originated in the U.S., with $67 \%$ of large mills identifying the international border as highly important to their mill's success. The U.S. exports about 7 million $\mathrm{m}^{3}$ of softwood sawlogs and 2 million $\mathrm{m}^{3}$ of hardwood sawlogs annually, with Canada as the destination for between $20 \%$ and $30 \%$ of all $\log$ exports in recent years (Howard 1999, 2006). Roundwood is a particularly important export for the Northern Forest states of Maine, Vermont, New York and New Hampshire. Among the mills included in the Chauedière-Appalaches study, these were the top 4 states for wood procured from the U.S., representing a combined $97 \%$ of the wood that originated across the border (Straussfogel et al. 2003).

In 2006, just over $28 \%$ of New York's roundwood was exported. Approximately $743000 \mathrm{~m}^{3}$ of logs ${ }^{4}$, representing $21 \%$ of the total sawlog harvest, was exported, with Canada receiving about $2 / 3$ of all exports of sawlogs and pulpwood from the state (Crawford 2007). Softwood logs are Maine's number 4 export overall, accounting for at least $\$ 150$ million USD per year in value (U.S. Census Bureau 2006). In 2005, $17 \%$ of Maine's total sawlog and pulpwood harvest went to Canada, with approximately $36 \%$ of the state's total 10 million $\mathrm{m}^{3}$ sawlog harvest exported from Maine without further processing (Maine DOC 2006, NEFA 2007a). In 2005, Vermont exported $66000 \mathrm{~m}^{3}$ of sawlogs and veneer to Canada, which represents 38\% of all interstate and international exports of these products (Vermont Division of Forestry 2006). Much of the roundwood harvested from New Hampshire's forests travels north to Canadian mills for processing. Of the 2.2 mil-

\footnotetext{
${ }^{4}$ Log volumes have been standardized to cubic meters based on conversion factors from Howard (1997).
}

lion $\mathrm{m}^{3}$ of sawlogs and pulp harvested in 2005, 13\% was exported to Canada (NEFA 2007b). In aggregate, approximately 3.9 million $\mathrm{m}^{3}$ of sawlogs and pulpwood, or $15 \%$ of the total combined harvest, are exported to Canada from these 4 states each year (NEFA 2007c).

The majority of the softwood log supply and a large percentage of the hardwood log supply from these 4 states originates in the region known as the Northern Forest, which is an area of approximately 12 million ha of relatively contiguous spruce-fir and mixed hardwood forest that stretches from Maine's border with New Brunswick, through Vermont and New Hampshire to the Tug Hill Plateau in New York (Fig. 1). In 1990, following Diamond International's sale of 400000 ha of industry lands, the U.S. Congress formed the Northern Forest Lands Council (NFLC) to study the future of the forests and communities in this region. The Council's work culminated in 1994 with the publication of comprehensive forest policy and management recommendations that included an emphasis on maintaining "traditional patterns of land ownership and use of the Northern Forest" (NFLC 1994), which continue to be heavily oriented toward conservation, tourism and the forest products industry. Accordingly, 1994 serves as a benchmark for this study.

Forest land in the Northern Forest is predominantly private, with between $80 \%$ and $96 \%$ of forest land held in private ownership, depending on the state. Private ownership is dominated by family forests (also called non-industrial private forests), but also includes a significant portion of industrial forests, and forest land owned by large real-estate investment and management firms. For example, in Maine, industrial and large investment ownerships account for $43 \%$ of all forest land, and nearly 50\% of ownerships larger than 2000 ha (Hagan et al. 2005).

In recent years, research in a number of different fields has shed light on ecological and socioeconomic trends that have the potential to impact the flow of roundwood from the Northeast's private forests to both Canadian and American primary forest products producers. Among these trends, urbanization and forest loss to development (Wear et al. 1999, Munn et al. 2002, Nowak and Walton 2005, Egan et al. 2007, Germain et al. 2007), parcelization of large ownerships (Butler and Leatherberry 2004, LaPierre and Germain 2005, Germain et al. 2006), changing ownership objectives (Dennis 1989), and exploitative harvesting practices (Fajvan et al. 1998, Nyland 2001, Kenefic and Nyland 2005, Munsell and Germain 2007) have been highlighted for their potential to negatively impact the flow of timber from private lands. Similar pressures may impact the flow of logs from Canada's 23 million ha of privately owned forest, which accounts for $19 \%$ of Canada's wood supply (Dansereau and deMarsh 2003, Rotherham 2003). It remains unclear what effects these and other trends may have on the long-term roundwood supply in the region.

\section{Objectives}

Despite an abundance of economic analysis devoted to crossborder trade in logs and lumber, especially regarding the softwood lumber trade dispute, significant gaps remain in our understanding of the connections between U.S. forests and Canadian sawmills. These gaps make it difficult to predict how a variety of biophysical, economic and policy changes on both sides of the border will impact Canadian mills. Working 


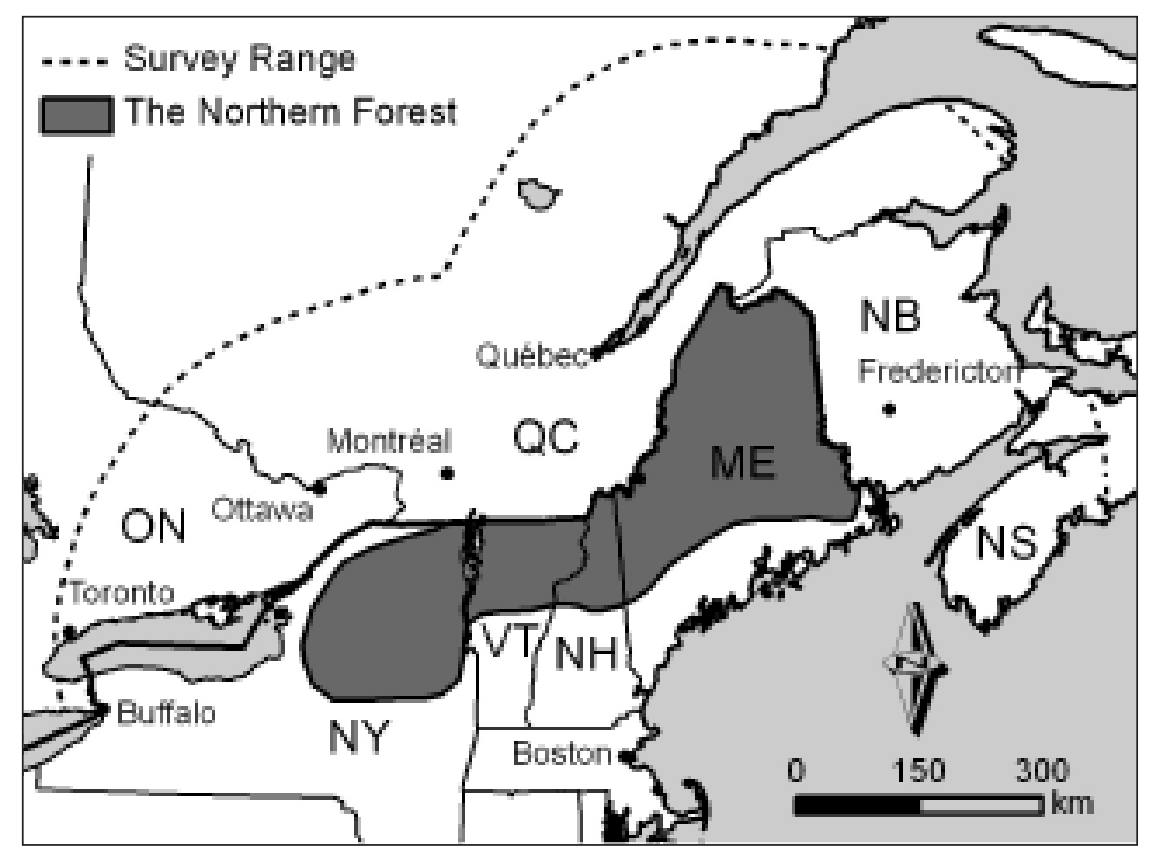

Fig. 1. Map of the study region. The survey targeted Canadian mills within $300 \mathrm{~km}$ of the Northern Forest.

to close some of these gaps, this paper examines the wood procurement operations of eastern Canadian sawmills and compares the perspectives of Canadian mill managers who are reliant on U.S. sawlog sources to those of mill managers who procure all or nearly all of their log supply within Canada. Specifically, we (1) quantify the utilization of U.S. log sources by Canadian sawmills within 300 kilometres of the Northern Forest, (2) provide estimates for the geographic range of sawmill wood procurement operations, (3) examine the relative importance of 4 specific sawlog sources, (4) compare perceptions of changes in log supply over a 10-year period from 1994 to 2005, and (5) use a logistic regression model to analyze the factors that influence procurement from U.S. $\log$ sources. This research provides valuable regional baseline data for future studies and contributes to our understanding of transborder wood flow and log procurement. It also provides insights into the potential of observed and predicted socioeconomic trends to impact transborder log supply, especially for mills that are heavily reliant on U.S. sources to meet production requirements.

\section{Methods}

Data collection

We used Dillman's Tailored Design Method (2000) to survey all Canadian sawmills within 300 kilometres of the boundary of the Northern Forest (Fig. 1). Our goal was to census all mills within this study region that processed roundwood in 2005. We developed our sample frame of mill addresses using a variety of government, NGO and industry sources (e.g., Natural Resources Canada 2003, GFWC 2004, Quebec Ministry of Natural Resources 2004, Ontario Ministry of Natural Resources 2005, Spelter and Alderman 2005), as well as company Web sites and Web-based business and industry association directories. In general, if we could not confirm that a mill processed roundwood in 2005 , it was included in the sample frame rather than dropped from the study. The result- ing sample frame included 452 sawmills ranging in size from less than $2000 \mathrm{~m}^{3}$ year-1 to more than $600000 \mathrm{~m}^{3}$ year-1 $^{-1}$ in reported production capacity.

The survey took place in the summer of 2006, with the first mailing sent on June 15, 2006. To address concerns about the potential of a low response rate for a Canadian mill survey originating from and returning to a university in the United States, all of the survey mailings included copies of letters of support from the Bas-St-Laurent and Eastern Ontario Model Forests, in addition to a bi-lingual cover letter, a copy of the questionnaire, and an international postagepaid business reply envelope. The first mailing was followed by a reminder letter, a replacement questionnaire, and a final contact letter, each mailed at 2week intervals.

The questionnaire included 20 openended and 14 close-ended questions that were designed to collect general mill information, identify the geographic range of procurement operations, quantify percentage of log supply originating in the U.S., evaluate perceptions of changes in log supply over a 10 - year period, and determine the relative importance of alternative $\log$ sources. To facilitate aggregation and comparison of the U.S. and Canadian samples, the survey instrument was developed to mirror a questionnaire used by the authors to survey U.S. sawmills the same year (Anderson and Germain 2007), with a few important differences. The Canadian survey was bilingual and metric, with all questions presented in both French and English. Several questions were adapted to apply more appropriately to Canadian sawmills. For example, based on recommendations from industry partners involved in survey development, the general U.S. category of "leases and easements" was replaced by the "provincial Crown lands" category and the category "gatewood" was dropped. All questions were developed with feedback from 14 industry professionals in the U.S. and Canada, including mill managers, procurement foresters, log buyers, and industry association representatives, as well as 2 foresters from the Canadian Model Forest Network.

The first set of questions was focused on identifying the respondent as an appropriate mill agent, that is, someone responsible for purchasing roundwood and/or recording volume information about roundwood purchases. The next set of questions established the geographic extent of the mill's wood procurement region, also known as its "woodshed." Based on a regional map and a distance scale presented in the questionnaire, respondents were asked to estimate the radius of their woodshed by drawing a line around the area that supplies the closest $90 \%$ of their total annual log volume, then estimating the average distance to the drawn boundary in an open-ended question. Two additional open-ended questions established the farthest distance to stumpage and the farthest distance a load of logs has traveled to the mill.

In assessing the relative importance of different log sources within respondent woodsheds, this study focused on 4 alter- 
native sawlog sources: fee simple lands (owned by the company or mill proprietor), provincial Crown lands, stumpage, and roadside wood. Stumpage is purchased by the firm as standing timber and roadside wood includes logs purchased by bid or direct sale from a log landing or concentration yard not owned by the firm. Respondents were asked to estimate the percentage by volume of their total 2005 log supply that was procured from each of these sources. We also included an "other" category, with a space for explanation. Responses were based on total 2005 log supply and not further divided by country of origin (i.e., roundwood identified as "roadside" could have been purchased in either the U.S. or Canada). However, respondents were asked to report the percentage of their total $2005 \log$ supply that originated in the United States.

In addition to the open-ended, quantitative responses, respondents were asked to offer their perceptions of changes in log supply within their woodshed since 1994, the year the NFLC released its management recommendations. The questions evaluated changes in the total volume of logs available for purchase, the quality of logs available for purchase, and the average volume per log. Several other questions evaluated changes in stumpage as a log source. Opinion questions solicited responses on an ordinal scale with 5 response options: increased significantly (by more than 10\%), increased a little (by less than 10\%), stayed the same, decreased a little (by less than 10\%), and decreased significantly (by more than $10 \%$ ).

\section{Statistical analysis}

We examined the effects of mill type, transborder log procurement, and mill size on procurement variables using an unbalanced factorial design. Using a 50\% threshold, mills were categorized as either softwood or hardwood based on the reported percentage of their total $2005 \log$ volume that was hardwood. Mills also were categorized into 2 groups based on the percentage of their 2005 log volume that originated in the U.S., with mills reporting zero transborder procurement grouped together. In addition, mills were placed in 3 size classes based on the consumption classes used by the Québec Ministry of Natural Resources (Straussfogel et al. 2003) and the classes presented in the National Atlas of Canada (Natural Resources Canada 2003). Large mills reported a total 2005 procurement volume greater than 100 $000 \mathrm{~m}^{3}$, medium mills reported between $30000 \mathrm{~m}^{3}$ and 99 $999 \mathrm{~m}^{3}$, and small mills reported between $2000 \mathrm{~m}^{3}$ and 29 $999 \mathrm{~m}^{3}$. Non-response bias was evaluated by comparing the responses of 63 respondents to those of 18 late respondents, who responded to the survey more than 60 days after the initial mailing. Though not ideal, using late respondents as a proxy for potential non-respondents in assessing nonresponse bias has been supported by previous studies (Ellis et al. 1970, Armstrong and Overton 1977).

Multivariate analysis of variance (MANOVA) and univariate analysis of variance (ANOVA) were used to compare group means of continuous response variables, including the 3 measures of woodshed extent. Due to the unbalanced sample sizes, type III sums of squares and least-squares means were used in these analyses. We used $\mathrm{F}$ approximations based on Wilks' Lambda to determine significance in MANOVA. Due to skewed distributions present in the data, the Chisquare statistic of the nonparametric Kruskal-Wallis test was used to evaluate differences in percentage estimates for alternative roundwood sources among sawmill groups. Comparisons of ordinal survey responses for opinion questions were based on 3 aggregate response categories (increased, stayed the same, and decreased) and were evaluated using Fisher's exact test.

Using a novel approach in this field, we also developed a logistic model to predict the use of U.S. log sources based on 4 predictor variables: distance from the U.S. border, percent of log supply from provincial Crown lands, total annual volume, and percent of log supply in hardwoods:

$$
\begin{aligned}
& \text { Model: } \quad P(Y=1)=\frac{1}{1+e^{-X}} \\
& \text { where } \\
& Y=1 \text { if mill procured U.S. logs, } 0 \text { if all logs originated } \\
& \text { in Canada } \\
& X=\beta_{0}+\beta_{1} \times Z_{1}+\beta_{2} \times Z_{2}+\beta_{3} \times Z_{3}+\beta_{4} \times Z_{4} \\
& Z_{1}=\text { Distance to U.S. border }(\mathrm{km}) \\
& Z_{2}=\text { Percentage of log supply from provincial Crown } \\
& \text { lands } \\
& Z_{3}=\text { Annual volume }\left(\mathrm{cm}^{3}\right) \\
& Z_{4}=\text { Percentage of annual volume in hardwoods } \\
& \beta_{1, \ldots, 4}=\text { coefficients to be estimated }
\end{aligned}
$$

These predictor variables were selected and hypothesized to be significant predictors based on results from previous studies (Anderson and Germain 2007; Straussfogel et al. 2003) and based on economic theory related to transfer costs (Bressler and King 1970). We expected mills distant from the border and mills with access to provincial Crown lands to be less likely to procure wood in the U.S., and hypothesized negative coefficients for these variables. Conversely, previous sawmill studies indicated that large mills would probably procure more wood from the United States than small mills. We expected hardwood mills to procure more wood from the U.S. than softwood mills because hardwood mills in the U.S. tend to have larger woodsheds than softwood mills (Anderson and Germain 2007), and the hardwood resource is more extensive in the U.S. than in Canada. The model was evaluated using a variety of statistics including a likelihood ratio Chi-square test, which tests the null hypothesis that all of the predictors' regression coefficients are equal to zero, and the Akaike information criterion (AIC), which is used to compare alternative models based on negative log likelihood and a bias correction factor.

A significance level of alpha $=0.10$ was used for all statistical tests, with the exception of interaction among treatment factors (grouping variables) in MANOVA and ANOVA, which was considered significant if the p-value was below 0.20. Confidence intervals are shown at the $95 \%$ level. SAS software version 9.1 (SAS Institute Inc. 2004) was used for all calculations and statistical tests.

\section{Results}

\section{The respondents}

From the 452 valid sawmill addresses we surveyed, 128 questionnaires were returned. Of those, 48 were not applicable to this study because the mill has never or no longer processes roundwood, processed less than $2000 \mathrm{~m}^{3}$ in 2005, or closed before the end of 2005. Four of the respondents failed to pro- 
Table 1. Sample sizes for sawmill groups based on mill size class and procurement from U.S. log sources

\begin{tabular}{|c|c|c|c|}
\hline \multirow{2}{*}{$\begin{array}{l}\text { Mill size } \\
\left(1000 \mathrm{~m}^{3} / \mathrm{yr}\right)\end{array}$} & \multicolumn{3}{|c|}{ U.S. log procurement } \\
\hline & Yes & No & Total \\
\hline$>100$ & 9 & 5 & 14 \\
\hline 30 to 99 & 12 & 15 & 27 \\
\hline 2 to 29 & 15 & 20 & 35 \\
\hline Total & 36 & 40 & 76 \\
\hline
\end{tabular}

vide sufficient information to place their mill in an appropriate sawmill group. The resulting minimum response rate of $19 \%$ is based on 76 respondents and 328 non-respondents. None of the 3 sawmill grouping variables (mill type, mill size, and transborder procurement) showed any significant effect on the time of response, with a median response time of 38 days for the entire sample. Using late respondents as a proxy for potential non-respondents, 1 question of the 19 survey questions for which non-respondent bias is relevant showed non-response bias at the alpha $=0.10$ level. Respondents who completed and returned the survey within 2 months had a higher median percentage of log supply from provincial Crown lands when compared to late respondents, with medians of $25 \%$ and $5 \%$ respectively $(p=0.1009)$. None of the other response variables exhibited any significant difference between respondents and late respondents.

In aggregate, these 76 respondents represent at least 5.17 million $\mathrm{m}^{3}$ of $\log$ procurement in 2005, with an average 2005 procurement volume of $68100 \mathrm{~m}^{3}$ per mill. Of the total reported procurement, 4.23 million $\mathrm{m}^{3}$ (83\%) was softwood and 0.87 million $\mathrm{m}^{3}$ (17\%) was hardwood. For comparison, Québec and Ontario together produced a total of 26.2 million $\mathrm{m}^{3}$ of softwood lumber and 1.5 million $\mathrm{m}^{3}$ of hardwood lumber in 2005 (Statistics Canada 2006). New Brunswick and Nova Scotia accounted for an additional 5.2 million $\mathrm{m}^{3}$ of softwood lumber and 0.2 million $\mathrm{m}^{3}$ of hardwood lumber in 2005. However, our sample frame did not include all mills in these provinces, but only those within 300 kilometres of the Northern Forest. Most of the mills in Ontario and a large number of mills in western Québec were not included in the sample frame. By subtracting the aggregate reported production capacity of sawmills outside of our sample range from government production statistics for the provinces (Statistics Canada 2006), we estimate that the sample represents more than $30 \%$ of softwood procurement and more than $60 \%$ of the hardwood procurement in the study region. Over 1.75 million $\mathrm{m}^{3}(34 \%)$ of the total roundwood volume reported in the survey came from U.S. sources. This figure accounts for $45 \%$ of the reported 3.9 million $\mathrm{m}^{3}$ of sawlogs and pulpwood exported to Canada from the 4 Northern Forest states (NEFA 2007c).

Three continuous variables were used to place sawmills into groups: total 2005 procurement volume, percent of 2005 procurement volume in hardwoods, and percent of 2005 procurement volume originating in the United States. Sample sizes for the 3 mill size classes and transborder log procurement groups are shown in Table 1. Fourteen large mills (18\%) procured $100000 \mathrm{~m}^{3}$ or more in 2005, with 27 mills (36\%) in
Table 2. Comparison of mean distances to roundwood by procurement group. Standard error is in parentheses

\begin{tabular}{lcccc}
\hline & \multicolumn{4}{c}{ U.S. log procurement } \\
\cline { 2 - 5 } Distance & Yes & No & F & p-value \\
\hline $\begin{array}{l}\text { Distance } \\
\text { encompassing }\end{array}$ & 240 & 114 & 17.52 & $<0.0001$ \\
$\begin{array}{l}\text { 90\% of log supply } \\
\text { in 2005 (km) }\end{array}$ & $(22.0)$ & $(20.6)$ & & \\
$\begin{array}{l}\text { Farthest distance } \\
\text { to stumpage (km) }\end{array}$ & $\begin{array}{l} \\
\end{array}$ & & & \\
$\begin{array}{l}\text { Farthest distance } \\
\text { to logs (km) }\end{array}$ & $440.9)$ & $(26.4)$ & & \\
\hline
\end{tabular}

the medium size class (30 000 to $99999 \mathrm{~m}^{3}$ ) and 35 (46\%) in the small size class (2000 to $29999 \mathrm{~m}^{3}$ ). Based on the $50 \%$ threshold, 27 mills were classified as hardwood mills and 49 as softwood mills. Most mills were either heavy to hardwood or heavy to softwood, with only 5 mills reporting mixed procurement between $30 \%$ and $70 \%$ hardwood by volume. Compared to the overall structure of the industry in 2005, this sample adequately represents the hardwood lumber industry (Natural Resources Canada 2003), but appears to under-represent large softwood mills, which account for over half of the softwood mills in this region (Natural Resources Canada 2003, Spelter and Alderman 2005). Even so, large softwood mills do account for the largest proportion of the aggregate reported log volume, representing $57 \%$ of total procurement reported in the survey. Thirty-six mills reported procuring at least some of their 2005 log supply from the United States, while 40 mills procured $100 \%$ of their supply from Canada. Of the mills procuring some of their supply from the U.S., 22, or $61 \%$, procured more than $1 / 2$ of their total log supply from south of the border.

\section{Distance to wood supply}

The mean woodshed radius, defined as the average distance encompassing $90 \%$ of total log supply, was $173 \mathrm{~km}$ over the entire sample. However, these mills can range much farther to meet roundwood requirements, with a mean farthest distance to stumpage of $226 \mathrm{~km}$ and a mean farthest distance to logs of $320 \mathrm{~km}$. When these 3 measures of woodshed extent are evaluated simultaneously in MANOVA, neither mill size class ( $\mathrm{p}$ $=0.9358)$ nor mill type $(\mathrm{p}=0.5681)$ have a significant effect on the mean vector of the 3 distances. Transborder wood procurement does have a significant effect on the mean vector of procurement distances $(\mathrm{p}=0.0045)$, with no significant multivariate interactions among the 3 factors used to differentiate mill groups.

In univariate analysis, mill size shows no effect on mean woodshed radius, farthest distance to stumpage, or farthest distance to logs ( $\mathrm{p}=0.6941,0.6831$, and 0.9093 , respectively). Mill type shows a similar lack of effects $(\mathrm{p}=0.8365,0.8950$, and 0.6499 , respectively) with regards to these variables. Transborder procurement does have a significant effect on all 3 variables (Table 2). Mills reliant on U.S. log sources range farther to procure roundwood, with a mean woodshed radius 


\begin{tabular}{|c|c|c|c|c|}
\hline \multirow[b]{2}{*}{ Variable } & \multirow[b]{2}{*}{ Source } & \multirow[b]{2}{*}{ All mills $(n=76)$} & \multicolumn{2}{|c|}{ U.S. log procurement } \\
\hline & & & Yes $(\mathbf{n}=35)$ & No $(n=39)$ \\
\hline Mean \% reported & Fee lands & $9.9(2.33)$ & $10.6(3.72)$ & $9.2(2.95)$ \\
\hline \multirow[t]{4}{*}{ mean (std. error) } & Provincial Crown lands & $32.9(4.16)$ & $12.6(3.79)$ & $51.1(5.78)$ \\
\hline & Stumpage & $14.6(2.57)$ & $13.6(3.94)$ & $15.6(3.42)$ \\
\hline & Roadside & $37.4(4.40)$ & $56.5(6.78)$ & $20.4(4.18)$ \\
\hline & Other & $6.6(2.38)$ & $9.6(4.36)$ & $3.9(2.26)$ \\
\hline Total volume $\left(1000 \mathrm{~m}^{3}\right)$ & Fee lands & $444(8.6 \%)$ & $323(11.7 \%)$ & $121(5.0 \%)$ \\
\hline \multirow[t]{5}{*}{ total (\% of group. total) } & Provincial Crown lands & $2219(42.8 \%)$ & $453(16.4 \%)$ & $1766(73.1 \%$ \\
\hline & Stumpage & $692(13.4 \%)$ & $426(15.4 \%)$ & $266(11.0 \%)$ \\
\hline & Roadside & $1090(21.0 \%)$ & $896(32.4 \%)$ & $193(8.0 \%)$ \\
\hline & Other & $734(14.2 \%)$ & $665(24.1 \%)$ & $69(2.9 \%)$ \\
\hline & Group total & $5178(100 \%)$ & $2763(100 \%)$ & $2415(100 \%)$ \\
\hline
\end{tabular}

over twice that of mills that procured $100 \%$ of their log supply within Canada (240 km and $114 \mathrm{~km}$, respectively). The trend was equally pronounced for farthest distance to logs (445 km and $220 \mathrm{~km}$ ), and significant but less pronounced for farthest distance to stumpage $(277 \mathrm{~km}$ and $190 \mathrm{~km})$. Interactions among the 3 factors used to differentiate mill groups in ANOVA models were not significant.

\section{Roundwood sources}

Among the 4 log sources evaluated, provincial Crown lands were the largest single source of roundwood, supplying around $43 \%$ of the 5.17 million $\mathrm{m}^{3}$ represented by the survey (Table 3). Roadside wood purchased by bid or direct sale accounted for $21 \%$, with fee lands, stumpage and "other" accounting for $9 \%, 13 \%$ and $14 \%$, respectively. Most respondents did not provide an explanation for "other" in the space provided, but common responses included "gatewood," procurement from other mills owned by the same firm, and procurement from mills owned by other firms. "Other" marked explicitly by the respondent as gatewood accounted for 53\% of the total volume of $734200 \mathrm{~m}^{3}$ reported in this category.

As with distances to roundwood, mill type and size class did not have a significant effect on any of the 5 source variables. U.S. log procurement had a significant effect on 2 of the 5 source groups: provincial Crown lands and roadside, with $p$ $<0.0001$ for both sources. Procurement from the other 3 sources did not differ significantly between the 2 groups. Provincial Crown lands provided the bulk of roundwood, $73 \%$ by volume, for mills that procured $100 \%$ of their 2005 roundwood supply in Canada, with relatively lower reliance on roadside and stumpage, which accounted for $8 \%$ and $11 \%$ by volume, respectively (Table 3 ). In contrast, mills that procured wood from the U.S. most heavily favoured roadside sources, which accounted for $32 \%$ by volume. The "other" category, which includes a heavy component of gatewood, accounted for $24 \%$, followed by provincial Crown lands, stumpage, and fee lands at $16 \%, 15 \%$ and $12 \%$, respectively.

\section{Perceptions of changes in wood supply}

We were also interested in evaluating perceptions of changes in log supply over the decade between 1994 and 2005. The results of these opinion questions point toward perceived declines in log quality, as well as declines in volume per log over that period, accompanied by an increase in average distance to stumpage purchases for many firms that have stumpage as a component of their log supply (Table 4). Over $1 / 2$ of respondents reported that the quality of logs available for purchase declined over the study period, $60 \%$ reported an overall decline in volume per log, and $54 \%$ indicated increased average distance to stumpage purchases. In contrast, ordinal responses for the total volume of logs available for purchase and the average volume of an individual stumpage purchase are centered on a median response of "stayed the same." In comparing the 2 transborder procurement groups, there appears to be a difference between the 2 groups with regards to volume of logs available for purchase, with $42 \%$ of respondents with U.S. log sources reporting an increase in logs available for purchase between 1994 and 2005 , and $44 \%$ of mills with no U.S. sources reporting a decline over the same period (Table 5). Similarly, a larger percentage of mills using only Canadian roundwood sources reported a decline in the quality of logs available for purchase. However, these differences are not statistically significant $(\mathrm{p}=$ 0.2564 and 0.1954 , respectively). The perception of changes in volume per log is also not significantly different between the 2 groups $(\mathrm{p}=0.6757)$.

\section{Logistic regression model}

We used a logistic regression model to predict the use of U.S. log sources based on 4 covariate mill characteristics: distance from the U.S. border, percent of log supply from provincial Crown lands, total annual volume, and percent of log supply in hardwoods. Among the 4 covariates, 2 correlations were significantly different from zero. Percent of log supply from provincial Crown lands was positively correlated with distance from the border $(r=0.600, p<0.0001)$ and total annual volume was negatively correlated with percent hardwood $(\mathrm{r}=-0.268, \mathrm{p}=0.0208)$. An analysis of maximum likelihood estimates for the coefficients of the model is shown in Table 6 . Among the variables included in this model, distance to the U.S. border had the highest level of significance $(p=0.0025)$, followed by the percent of total log supply originating on provincial Crown lands $(\mathrm{p}=0.0051)$. These 2 variables are similar in terms of the magnitude of their coefficients and have the greatest impact on the model, even when the effects of units are eliminated with standardization. As expected, coeffi- 
Table 4. Perceptions of trends in log supply between 1994 and 2005 . Chi-square tests the null hypothesis of equal proportions.

\begin{tabular}{|c|c|c|c|c|c|}
\hline \multirow[b]{2}{*}{ Variable } & \multicolumn{5}{|c|}{ Responses (\%) } \\
\hline & Increased & Same & Decreased & Chi-square & p-value \\
\hline Volume of logs available for purchase & $25(34 \%)$ & $22(30 \%)$ & $27(36 \%)$ & 0.5135 & 0.7736 \\
\hline Quality of logs available for purchase & $10(14 \%)$ & $26(35 \%)$ & $38(51 \%)$ & 16.0000 & 0.0003 \\
\hline Volume per log & $6(3 \%)$ & $26(37 \%)$ & $42(60 \%)$ & 26.3784 & $<0.0001$ \\
\hline Average distance to stumpage purchases & $21(54 \%)$ & $18(46 \%)$ & $0(0 \%)$ & - & - \\
\hline Average volume of an individual stumpage purchase & $7(20 \%)$ & $21(58 \%)$ & $8(22 \%)$ & 10.1667 & 0.0062 \\
\hline
\end{tabular}

Table 5. Perceptions of trends in log supply between 1994 and 2005 by procurement group. Fisher's exact test tests the null hypothesis of equal distributions, with $95 \%$ confidence interval shown in parentheses. Questions for stumpage purchases are not included due to small cell frequencies.

\begin{tabular}{|c|c|c|c|c|c|c|c|}
\hline \multirow[b]{3}{*}{ Variable } & \multicolumn{7}{|c|}{ U.S. log procurement } \\
\hline & \multicolumn{3}{|c|}{ Yes } & \multicolumn{3}{|c|}{ No } & \multirow[b]{2}{*}{$\begin{array}{c}\text { Fisher's } \\
\text { exact test }\end{array}$} \\
\hline & Increased & Same & Decreased & Increased & Same & Decreased & \\
\hline Volume of logs available for purchase & $15(42 \%)$ & $10(29 \%)$ & $10(29 \%)$ & $10(26 \%)$ & $12(31 \%)$ & $17(44 \%)$ & $\begin{array}{c}0.2564 \\
( \pm 0.0112)\end{array}$ \\
\hline Quality of logs available for purchase & $6(17 \%)$ & $15(43 \%)$ & $14(40 \%)$ & $4(10 \%)$ & $11(28 \%)$ & $24(62 \%)$ & $\begin{array}{c}0.1954 \\
( \pm 0.0102)\end{array}$ \\
\hline Volume per log & $2(6 \%)$ & $14(40 \%)$ & $19(54 \%)$ & $4(10 \%)$ & $12(31 \%)$ & $23(59 \%)$ & $\begin{array}{c}0.6757 \\
( \pm 0.1210)\end{array}$ \\
\hline
\end{tabular}

Table 6. Analysis of maximum likelihood estimates for the logistic model predicting the use of U.S. log sources based on 4 covariates.

\begin{tabular}{|c|c|c|c|c|c|c|c|}
\hline \multicolumn{2}{|c|}{ Parameter } & \multirow{2}{*}{$\begin{array}{c}\text { Estimate } \\
1.8236\end{array}$} & \multirow{2}{*}{$\begin{array}{c}\begin{array}{c}\text { Std. } \\
\text { error }\end{array} \\
0.7142\end{array}$} & \multirow{2}{*}{$\begin{array}{c}\begin{array}{c}\text { Stdzd. } \\
\text { estimate }\end{array} \\
-\end{array}$} & \multirow{2}{*}{$\begin{array}{c}\text { Chi-square } \\
6.5199\end{array}$} & \multirow{2}{*}{$\begin{array}{c}\text { p-value } \\
0.0107\end{array}$} & \multirow{2}{*}{$\begin{array}{c}\begin{array}{c}\text { Est. odds } \\
\text { ratio }\end{array} \\
6.194 \\
\end{array}$} \\
\hline $\mathrm{Z}_{0}$ & Intercept & & & & & & \\
\hline$Z_{1}^{0}$ & Distance to U.S. border $(\mathrm{km})$ & -0.0224 & 0.00742 & -0.9549 & 9.1229 & 0.0025 & 0.978 \\
\hline $\mathrm{Z}_{2}$ & $\%$ of log supply from provincial Crown lands & -0.0423 & 0.0151 & -0.8353 & 7.8275 & 0.0051 & 0.959 \\
\hline $\mathrm{Z}_{3}^{2}$ & Annual volume $\left(\mathrm{cm}^{3}\right)$ & $8.29 \mathrm{E}-6$ & $3.578 \mathrm{E}-6$ & 0.4974 & 5.3677 & 0.0205 & 1.000 \\
\hline$Z_{4}^{3}$ & $\%$ of annual volume in hardwoods & 0.0103 & 0.00863 & 0.2437 & 1.4324 & 0.2314 & 1.010 \\
\hline
\end{tabular}

cients for both of these variables are negative, with mills further from the border and mills with provincial Crown land log sources less likely to purchase roundwood from the United States. Large mills are more likely to have U.S. sources $(\mathrm{p}=$ 0.0205), but the percentage of total log supply in hardwoods was not a significant variable in the model $(\mathrm{p}=0.2314)$. The model correctly predicts the use of U.S. log sources for $94 \%$ of the mills in the sample and has a likelihood ratio Chi-square test of 50.8 ( $p<0.0001)$, which rejects the null hypothesis that all of the predictors' regression coefficients are equal to zero. The logistic model including the 4 covariates is stronger than the model with intercept alone, with AIC values of 61.3 and 104.1, respectively. The model including all 4 covariates is also stronger than all permutations of the model using less than 4 covariates; the second-best model includes only the intercept, distance to border, and percent of log supply from provincial Crown lands $(\mathrm{AIC}=62.4)$.

\section{Discussion}

It is expected that mills reliant upon U.S. roundwood sources would travel farther for logs. In fact, these mills may have double the woodshed radius of mills that procure their roundwood entirely within Canada. Even mills procuring less than $30000 \mathrm{~m}^{3}$ per year may routinely range $180 \mathrm{~km}$ or more for roundwood. As has been the subject of intense scrutiny by U.S. interests during the softwood lumber trade dispute, access to provincial Crown lands is decided by both administrative processes and market forces. Our study indicates that access to provincial Crown lands for logs is a significant factor in predicting if a mill relies on U.S. forests for part or all of its roundwood supply. Results suggest that mills with little or no log supply from provincial Crown lands are more likely to procure wood in the United States. Although mills with access to provincial Crown land leases may enjoy competitive advantage in terms of wood supply security and lower trans- 
portation costs, contractual obligations to use the wood committed to them may limit their ability to procure logs from other sources, regardless of market conditions, perhaps foregoing opportunities to purchase larger, higher-quality logs in the United States.

Straussfogel et al. (2003) and others have highlighted the cost of roundwood as the dominant cost of production for most sawmills. With regards to the size of a mill's woodshed, procurement costs are likely to limit the geographic extent of procurement operations, all else being equal (Bressler and King 1970). In theory, increasing procurement costs reduces the extent of procurement operations if increasing costs are not accompanied by increasing lumber prices. As a component of transport costs, the cost of fuel and the recent rise in fuel prices has the potential to reduce the distance that Canadian mills can range efficiently for wood. Over the last year, on-road diesel fuel prices in the U.S. have climbed $63 \%$ from $\$ 0.76 \mathrm{CAD}$ per litre to an average of $\$ 1.24 \mathrm{CAD}$ per litre in June, 2008. Prices in Canada rose 49\% from $\$ 0.97$ CAD per litre to $\$ 1.45 \mathrm{CAD}$ per litre over the same period. However, U.S. logs are often a backhaul associated with delivering lumber to markets in the U.S., which tempers the impact of fuel prices on log transport costs. In contrast, though U.S. mills have smaller average procurement regions than both Canadian transborder procurement groups (Anderson and Germain 2007), they might be harder hit by high fuel prices because transport related to roundwood delivery is traditionally separate from lumber transport. Again, given the significant difference in transport distance for mills that have access to provincial Crown lands, any comparative advantage that access brings would clearly be intensified as fuel costs rise.

Both the Canadian mills in this study and their American counterparts (Anderson and Germain 2007) reported trends toward declining log quality and volume per log between 1994 and 2005. Whether the perceptions of sawmill managers represent the true condition of the sawlog resource has been debated (Luppold and Dempsey 1996), but such trends would be expected as a result of exploitative harvesting practices or limited access due to changes in the ownership and use of private forests in the United States. Regardless of the cause, if the resource is truly in decline, the supply of high-quality sawlogs in the Northern Forest should be expected to decline as well, potentially leading to higher prices if demand for high-quality logs remains strong. Over the last 50 years, sawmills in both countries have experienced productivity gains from technological advancements in sawing, drying and grading, which have improved recovery from lower-quality and smaller-diameter logs (Ince 1999). In an environment of declining log quality and intensified competition for quality sawlogs, incentives for individual mills to incorporate advanced technology may be stronger than ever. Rising prices would also provide additional incentives for landowners to manage for high-quality sawlogs, potentially providing a counterbalance to the short-term gains of exploitative harvesting practices.

The recent strength of the Canadian dollar against the U.S. dollar has improved the position of mills purchasing roundwood in the U.S., but applies a downward pressure on imports of Canadian lumber to U.S. markets, which are currently slumping as a result of the dramatically depressed U.S. housing market. Given that demand for roundwood is derived from the demand for lumber, it is not clear that the strong Canadian dollar will translate directly into an overall advan- tage for Canadian mills, especially if demand for Canadian products suffers. Furthermore, if the efficiency of the U.S. log supply to Canadian mills is dependent on backhaul from lumber delivery to U.S. markets, weakened U.S. sales due to currency fluctuations or recession in the U.S. would constrain the ability of Canadian mills to use U.S. logs to supply lumber markets in Canada and abroad. High fuel prices will only aggravate this reality.

Increased competition for quality sawlogs from the Northern Forest also has the potential to precipitate a shift in the relative importance of different sawlog sources. Currently, both Canadian mills with U.S. procurement and large U.S. mills (Anderson and Germain 2007) rely on roadside sources for between $20 \%$ and $40 \%$ of log supply, on average. Furthermore, gatewood (considered by some to be interchangeable with roadside wood) represents $46 \%$ of the U.S. log supply and perhaps $10 \%$ of the Canadian supply in this region. Stumpage accounts for $16 \%$ of the log supply for U.S. mills and $13 \%$ for the Canadian mills. If competition for roadside and gatewood sources intensifies, stumpage may become a more attractive option for procurement, despite the fixed costs associated with purchasing and managing stumpage sales. Canadian mills may be at a disadvantage in purchasing stumpage in the United States because of the relatively longer distance to evaluate and manages these sales. Furthermore, declines in average parcel size in much of the Northeast U.S. (Butler and Leatherberry 2004, LaPierre and Germain 2005, Germain et al. 2006) may further reduce the profitability of purchasing stumpage from family forest owners because fixed costs are spread over smaller average sales, leading to declining economies of scale in stumpage procurement. Though the results of this survey do not support the contention that Canadian mills experienced an overall decline in the average volume of individual stumpage purchases over the study period, nearly $40 \%$ of U.S. mills did report such a trend (Anderson and Germain 2007).

Trends that increase the costs of American roundwood may also intensify harvesting on Canadian private lands. Given that provincial Crown lands represent $88 \%$ of timberproductive forest land and supply around $80 \%$ of the annual harvest in Canada (Dansereau and deMarsh 2003), it may be a foregone conclusion that mills without access to these lands buy logs from U.S. suppliers. Alternatively, these mills could purchase a larger portion of their requirements from Canadian private lands, both industrial and non-industrial, which currently supply about $19 \%$ of Canada's annual harvest.

The relative importance of alternative sawlog sources has implications for the production of certified lumber. Those mills relying heavily on gatewood and roadside sources are unlikely to be able to guarantee the chain of custody, or if they can, may incur high costs to do so. Mills with provincial Crown leases can more easily track logs from the stump and therefore can guarantee an unbroken chain of custody at lower cost. Procurement from stumpage sales in the U.S. offers the potential for maintaining a clear chain of custody, but may also present higher procurement costs compared to roadside and gatewood. Under certification systems dominated by rigid chain of custody requirements, procurement from provincial Crown lands may offer a competitive advantage. However, in a procurement environment dominated by wood that is difficult to track, the incorporation of flexible accounting into existing certification systems may improve the efficiency of bringing certified products to market. 
The interdependence between Canadian sawmills and U.S. sawlog producers extends well beyond the immediate border and has important impacts on both the forests and the human communities in these 2 countries. This study shows that mills procuring the majority of their wood in Canada differ in some important ways from mills that import a large portion of their log supply from the United States. Further research should work to anticipate the impacts of social, economic and ecological changes on the transborder sawlog supply and the sawmill industry. Currently, we are using combined data sets from the U.S. and Canada to evaluate the intensity of competition for sawlogs across the Northern Forest, with the purpose of highlighting hotspots of competition for roundwood and predicting the impacts of observed changes in forest ownership and use on the sawlog supply from this region. This research includes geospatial analysis of competition based on detailed maps of the woodsheds of nearly 300 sawmills in both countries. A deeper understanding current and future wood supply will help improve the profitability and sustainability of the sawmill sector on both sides of the border.

\section{Acknowledgements}

The authors would like to thank Brian Barkley and Pierre Belleau of the Canadian Model Forest Network for their involvement in this project. Victor Brunette was a great help in survey development and translation. This research was funded by the Northeastern States Research Cooperative and would not have been possible without the support of sawmill managers throughout the United States and Canada.

\section{References}

Anderson, N. and R. Germain. 2007. Variation and trends in sawmill wood procurement in the Northeastern United States. Forest Products Journal 57(10): 36-44.

Armstrong, J. S. and T. S. Overton. 1977. Estimating nonresponse bias in mail surveys. Journal of Marketing Research 14(3): 396-402. Bressler, R. and R. King. 1970. Markets, Prices and Interregional Trade. John Wiley and Sons, New York. 426 p.

Butler, B. and E. Leatherberry. 2004. America's family forest owners. Journal of Forestry 102(7): 4-14.

Crawford, S. 2007. New York State industrial timber harvest production and consumption report, 2006. NYS Department of Environmental Conservation Forest Utilization Program, Albany, NY. 2 p.

Dansereau, J. and P. deMarsh. 2003. A portrait of Canadian woodlot owners in 2003. The Forestry Chronicle 70(4): 774-778.

Dennis, D. 1989. An economic analysis of harvest behavior: Integrating forest and ownership characteristics. Forest Science 35(4): $1088-1104$.

Dillman, D. 2000. Mail and Internet Surveys: The Tailored Design Method. John Wiley \& Sons, New York. 464 p.

Egan, A., D. Taggart and I. Annis. 2007. Effects of population pressure on wood procurement and logging opportunities in northern New England. Journal of Forestry 24(2): 85-90.

Ellis, R., C. Endo and J. Armer. 1970. The use of potential nonrespondents for studying nonresponse bias. The Pacific Sociological Review 23(2): 103-109.

Fajvan, M., S. Grushecky and C. Hassler. 1998. The effects of harvesting practices on West Virginia's wood supply. Journal of Forestry 96(5): 33-39.

Germain, R., N. Anderson and E. Bevilacqua. 2007. The effects of forest land parcelization and ownership transfers on nonindustrial private forest land forest stocking in New York. Journal of Forestry 105(8): 403-408.
Germain, R., K. Brazill and S. Stehman. 2006. Forest land parcelization in upstate New York despite economic stagnation and a declining population. Northern Journal of Applied Forestry 23(4): 280-287.

[GFWC] Global Forest Watch Canada. 2004. Canada's forest products mills. Global Forest Watch Canada, Edmonton, AB. Available at http://www.globalforestwatch.org/english/datawarehouse/index.asp Hagan, J., L. Irland and A. Whitman. 2005. Changing timberland ownership in the Northern Forest and implications for biodiversity. Report \# MCCS-FCP-2005-1, Manomet Center for Conservation Sciences, Brunswick, ME. 25 p.

Howard, J. 1997. U.S. timber production, trade, consumption, and price statistics 1965-1994. Gen. Tech. Rep. FPL-GRT-98. USDA Forest Service, Forest Products Laboratory, Madison, WI. 75 p.

Howard, J. 1999. U.S. timber production, trade, consumption, and price statistics 1965-1997. Gen. Tech. Rep. FPL-GRT-116. USDA Forest Service, Forest Products Laboratory, Madison, WI. 76 p.

Howard, J. 2006. U.S. forest products annual market review and prospects, 2002-2006. Research Note FPL-RN-0302. USDA Forest Service, Forest Products Laboratory, Madison, WI. 9 p.

Ince, P. 1999. Technological flexibility in the North American forest sector. In M. Palo and J. Uusivuori (eds.). World Forests, Society and Environment. Kluwer Academic Publishers, Dordrecht, The Netherlands.

Kenefic, L. and R. Nyland (eds.). 2005. Proceedings of the conference on diameter-limit cutting in northeastern forests, 2005. Gen. Tech. Rep. NE-341. USDA Forest Service, Northeastern Research Station. Newtown Square, PA.

LaPierre, S. and R. Germain. 2005. Forest land Parcelization in the New York City Watershed. Journal of Forestry 103(3): 139-145.

Luppold, W. and G. Dempsey. 1996. Is eastern hardwood sawtimber becoming scarcer? Northern Journal of Applied Forestry 13(1): 46-49.

Maine [DOC] Department of Conservation. 2006. 2005 wood processor report. Maine Forest Service, Department of Conservation, Augusta, ME. 9p.

Munn, I., S. Barlow, D. Evans and D. Cleaves. 2002. Urbanization's impact on timber harvesting in the south central United States. Journal of Environmental Management 64: 65-76.

Munsell, J. and R. Germain. 2007. Woody biomass energy: An opportunity for silviculture on non-industrial private forest lands in New York. Journal of Forestry 105(8): 398-402.

Natural Resources Canada. 2003. Atlas of Canada: Sawmills Map. Available at http://atlas.nrcan.gc.ca/site/english/maps/environment. NEFA. 2007a. The economic importance and wood flows from Maine's forests, 2007. North East State Foresters Association, Concord, NH. 8 p.

NEFA. 2007b. The economic importance and wood flows from New Hampshire's forests, 2007. North East State Foresters Association, Concord, NH. 8 p.

NEFA. 2007c. The economic importance and wood flows the forests of Maine, New Hampshire, Vermont and New York, 2007. North East State Foresters Association, Concord, NH. 4 p.

[NFLC] Northern Forest Lands Council. 1994. Finding Common Ground: Conserving the Northern Forest. Northern Forest Lands Council, Concord, $\mathrm{NH}$.

Nowak, D. and J. Walton. 2005. Projected urban growth (2000-2050) and its estimated impact on the US forest resource. Journal of Forestry 103(8): 383-389.

Nyland, R. 2001. Forestry and silviculture in the northeast - past, present, and the probably future. In Proc. Soc. Am. For. 2000 National Convention, SAF Publication 01-02. pp. 319-325. Society of American Foresters, Bethesda, MD.

Ontario Ministry of Natural Resources. 2005. Ontario's Forest Industry Facility (Mill) Statistics, 1999 to 2003. Available at http://www.mnr.gov.on.ca/MNR_E000256.pdf.

Québec Ministry of Natural Resources. 2004. Wood industries. Available at http://www.mrnf.gouv.qc.ca/english/forest/publications/publications-resumee.jsp. 
Rotherham, T. 2003. Canada's privately owned forest lands: Their management and economic importance. The Forestry Chronicle 79(1): 106-109.

SAS Institute Inc. 2004. Base SAS 9.1 Procedures Guide. SAS Institute Inc., Cary, NC.

Spelter, H. and M. Alderman. 2005. Profile 2005: Softwood sawmills in the United States and Canada. Res. Pap. FPL-RP-630. USDA Forest Products Laboratory, Madison, WI. 85 p.

Statistics Canada. 2006. Sawmills and Planing Mills: December 2005. Catalogue No. 35-003-XIB, volume 59, number 12. Statistics Canada, Ottawa, Canada.

Straussfogel, D., T. Howard, S. Masse and D. Zhang. 2003. Transborder interactions in the sawmill industry of ChauedièreAppalaches, Québec: A survey analysis. The Forestry Chronicle 79(5): 936-947.
U.S. Census Bureau. 2006. County business patterns. Available at http://www.census.gov/epcd/cbp/view/cbpview.html.

Vermont Division of Forestry. 2006. Vermont Forest Resource Harvest Summary, 2005. Vermont Department of Forests, Parks and Recreation, Waterbury, VT. Available from http://www.vtfpr.org/ util/for_utilize_harvsumm.cfm.

Wear, D., R. Liu, J. Foreman and R. Sheffield. 1999. The effects of population growth on timber management and inventories in Virginia. Forest Ecology and Management 118: 107-115. 